\title{
Možnosti aplikace konceptu postmateriálního štěpení na substátních úrovních ${ }^{1}$
}

\author{
The Possibilities and Limits of Applying the Concept of Postmaterial Cleavage \\ on Sub-State Levels
}

Karolína MusilovÁ2

\begin{abstract}
The paper explores the possibility of application of the material-post-material cleavage at the local and regional levels of a political system. Although the concept was originally designed decades ago for application on the central (i.e. national) level of a political system, it is still relevant, even though for different reasons. On the basis of an analysis of the current state of research in the field and a critical evaluation of existing contributions to the topic, the paper seeks to delineate conditions under which the concept of cleavages may be applied at subnational levels of governance. The concept of multilevel governance is then used to define specific features of these levels and to test to possibility of such a shift. The results show that the concept can be used at the local and regional level; however, it is critical to amend the given definition of a cleavage, especially in terms of institutional manifestation.
\end{abstract}

Keywords: Cleavages; Postmaterial Cleavages; Local and Regional Level; Multilevel Governance

\section{1. Úvod}

Konflikty těžko slučitelných veřejných zájmů týkajících se regionálního a lokálního rozvoje na jedné straně a ochrany životního prostředí na straně druhé jsou stále součástí společenské diskuze a zásadně ovlivňují život lidí v postižených oblastech. Jedná se především o konflikty, v nichž je životní prostředí ohroženo z důvodu ekonomického využití lokality, tedy například těžbou surovin, výstavbou infrastruktury či extenzivním využíváním půdy, přičemž tyto aktivity mohou zvýšit

\footnotetext{
1 Výzkum byl podpořen Grantovou agenturou Univerzity Karlovy (projekt č. 256216 - Postmateriálni štépeni v systému viceúrovnovébo vládnutí Ceské republiky).

2 Interní doktorandka, Katedra politologie, Institut politologických studií, Fakulta sociálních věd, Univerzita Karlova, U Krřžže 8, 15800, Praha 5 - Jinonice / Department of Political Science, Institute of Political Studies, Faculty of Social Sciences, Charles University, Prague, Czech Republic. E-mail: karolina.musilova@fsv.cuni.cz.
} 
počet pracovních míst v oblasti či přispívat ke zvýšení energetické nezávislosti státu. K aktuálnosti těchto situací přispívá i současný populismus jak tradičních stran, tak nových politických hnutí slibujících nová pracovní místa a zabezpečení.

Př́kladem může být nedávná diskuze okolo prolomení těžebních limitů v Severních Čechách, spory provázející snahu zahájit těžbu břidlicových plynů v USA a dalších zemích či obtížné hledání míst pro vybudování významných dopravních staveb či uložiště jaderného odpadu. Tyto a jim podobné spory všude doprovází obrovský zájem veřejnosti, aktivní zasahování nejrůznějších politických aktérů a vznik nových zájmových sdružení, která se v konfliktu angažují at' už na jedné nebo druhé straně. Tyto konflikty kromě střetu zcela odlišných hodnotových postojů a velkého zájmu veřejnosti spojuje i to, že se často dotýkají pouze omezené lokality, jejich důsledky ale ovlivňují i další úrovně politického systému.

Nahlížet na tyto konflikty je možné z úhlu právního, ekonomického, veřejnosprávního i mnoha dalších. I z perspektivy politické vědy se lze zaměřit na různé dimenze konfliktu. S ohledem na komplexnost problému, hodnotové rozpory a snahu vystihnout projevy důležité pro politický systém jako celek byla $\mathrm{v}$ tomto textu zvolena perspektiva postmateriálního štěpení, ovšem za předpokladu určitých změn směrem $\mathrm{k}$ aplikaci na jinou než národní úroveň.

Nevyhnutelně se nabízí otázka, zda má vůbec v době, kdy vznikají strany nových typů a voličské chování se proměňuje, smysl se ke štěpení vracet. Vždyt' i hypotéza o zamrznutí stranických systémů postupně pozbyla platnosti a rozhodování voličů ovlivňuje stále více faktorů, v nichž hrají čím dál větší roli hlavně vhodně nasměrovaná politická komunikace stran a marketing. Přestože pưvodní podoba konceptu štěpení již současné realitě neodpovídá, existuje řada důvodů podporujících tezi, že tento koncept má stále co říct i současným badatelům. Zaprvé je to jeho poměrně velká flexibilita a otevřenost, na kterou upozorňuje napríklad V. Hloušek (2002: 404-405). Ten tvrdí, že slábnoucí vysvětlující potenciál rokkanovského modelu „(...) neznamená, že by se koncept konfliktních linií vyčerpal, ale znamená to, že potřebuje nové bádání, které by vyšlo z respektování faktu konce platnosti hypotézy o zamrznutí a snažilo se analyzovat paralelně ruku $\mathrm{v}$ ruce jdoucí procesy společenské restrukturalizace a proměny stranických spekter západních zemí“ (Hloušek 2002: 407). Díky této flexibilitě se otevřel prostor pro množství Rokkanových nástupců, kteři koncept nebo jeho jednotlivé prvky rozvíjeli mnoha odlišnými směry. Nelze opominout ani rozvoj metodologického zázemí a dřive nedostupné (nebo obtížně získatelné) zdroje dat, která taktéž umožňují nová zkoumání (Deegan-Krause 2006: 538).

Vedle otevřenosti a flexibility existuje další důvod, proč můžeme koncept štěpení stále považovat za relevantní. Přestože pưvodní pojetí již pro vysvětlení současných národních stranických systémů plně nedostačuje, jde stále o významný nástroj, jehož prostřednictvím lze zkoumat, jakým zpơsobem se společenské konflikty promítají v politickém systému. To lze velmi dobře využít při zkoumání politických jednotek na substátních úrovních, což je také cíl předkládaného textu. 
Důležitost lokální a regionální úrovně vládnutí díky procesu decentralizace $\mathrm{v}$ posledních letech až desetiletích roste, což vede mimo jiné $\mathrm{k}$ tomu, že jsou na ně stále častěji aplikovány teoretické př́stupy dřive vyhrazené pro celostátní úroveň (např́klad Hudák, Jüptner a Svoboda 2003; Balík 2008; Bubeníček a Kubálek 2010). Že se v př́padě štěpení jedná o koncept, který není mrtvý a stále nabízí možnosti dalšího bádání, naznačuje i skutečnost, že prestižní odborný časopis West European Politics věnoval této problematice $\mathrm{v}$ roce 2010 celé monotematické číslo a další texty vznikají i v současné době (př. Westinen 2015; Balík 2016).

Předkládaná teoretická přehledová studie má za cíl prozkoumat předpoklady, za kterých lze koncept postmateriálního štěpení aplikovat na substátní úrovně politického systému. Přidanou hodnotou textu je pak na základě tohoto přehledu snaha zodpovězení následujících výzkumných otázek:

Je koncept postmateriálního štépeni spojen výlučnè s národni úrovni?

Jaké jsou prédpoklady aplikace na substátni úrovnè?

Jaké jsou odlišné projevy na rĩzných úrovnich?

První část článku zkoumá současný stav odborné debaty a dosavadní aplikace konceptu štěpení mimo původní výzkumný rámec, a to jak po stránce funkční, tak po stránce geografické. Dojde k identifikování klíčových prací, které koncept posunuly dále nebo významným způsobem obohatily jeho současné pojetí, důraz bude potom kladen zejména na nejnovější př́spěvky. $V$ této části budou diskutovány i aktuálně přijímané definice štěpení a možnosti a limity jejich použití v substátním kontextu.

V klíčové části článku budou představeny a kriticky zhodnoceny dosavadní pokusy o aplikaci mimo národní úroveň. Snahou autorky bylo analyzovat ty texty, které spojují otázku postmateriálního štěpení s lokální nebo regionální úrovní, případně texty zabývající se štěpením na lokální a regionální úrovni obecně. Výběr zkoumaných textů byl stanoven tak, aby byly dostupné $\mathrm{v}$ anglickém nebo českém jazyce a $\mathrm{v}$ provedené rešerši ${ }^{3}$ odpovídaly různým kombinacím klíčových slov cleavages, local, regional a postmaterial. Zkoumání je zaměřeno především na otázky, jaké byly předpoklady autorů těchto př́spěvků, které aspekty konceptu upravili a jakým způsobem.

Druhá část textu se snaží možnosti aplikace štěpení na substátní úrovně ověřit prostřednictvím konceptu víceúrovňového vládnutí. Ten bude v kontextu článku použit jako nástroj, skrze nějž bude poukázáno na specifika substátních úrovní a prípadné problémy, které se mohou při přenášení teoretických konceptů mimo národní úroveň objevit. Prostřednictvím důkladné rešerše dojde $\mathrm{k}$ identifikování dosavadních pokusů použít víceúrovňové vládnutí tímto způsobem. Optika

\footnotetext{
3 Pro rešerši byly využity databáze dostupné ve zdrojích Fakulty sociálních věd (Web of Science, Scopus, EBSCO, JStor, ProQuest, CEEOL, databáze jednotlivých vydavatelů Taylor and Francis, SAGE a Willey), a profesní sítě Research gate a Academia.edu.
} 
víceúrovňového vládnutí byla zvolena z toho důvodu, že lokálně-politické systémy se v jednotlivých státech výrazně liší, a to jak funkčně, tak teritoriálně. Bylo proto třeba zaměřit se pouze na obecné společné charakteristiky, nikoliv na specifika jednotlivých systémů. Zároveň se optika víceúrovňového vládnutí často využívá pro otázky spojené s ochranou životního prostředí, což je jeden z klíčových projevů postmateriálního štěpení.

V Závěru dojde $\mathrm{k}$ systematizaci dosavadních př́stupů $\mathrm{k}$ použití štěpení na lokální a regionální úrovni, identifikaci hlavních problémů a př̀edstavení možných způsobů, jak se s nimi při aplikaci mimo původní rámec vyrovnat.

\section{Postmateriální štěpení ${ }^{4}$}

\section{a. Od Rokkana k aktuální debatě}

Před samotným zkoumáním postmateriálního štěpení je nutné zastavit se nad určitými aspekty štěpení obecně. S flexibilitou konceptu štěpení zmíněnou v úvodu tím souvisí debata o „širším“ a „užším“ pojetí štěpení (Hloušek 2007: 365). „Užšíi“ pojetí vychází z původní Rokkanovy práce, bere tedy v úvahu historickou perspektivu vzniku konfliktů a zároveň jejich hluboké zakořenění ve společenské struktuře. Takto důsledné pojetí ovšem využití konceptu značně limituje, protože žádná z nových dimenzí štěpení by již nebyla schopna naplnit pưvodní charakteristiky. Na druhou stranu, př́liš široké pojetí (např́klad Taylor a Rae 1970; Cordier 1996; Blaise, Blake a Dion 1990 či Veer 1994) má s původním konceptem společný pouze pojem štěpení, kterým je ale označena v podstatě jakákoliv společenská dichotomie.

Tuto flexibilitu lze nicméně sledovat již od počátku výzkumu štěpení a vede i k tomu, že podobně jako mnoho dalších společensko-vědních pojmů nemá štěpení zcela jednoznačnou definici. Většina autorů se shodne na tom, že v nejširším smyslu se jedná o odraz společenského konfliktu nebo rozdělení ve stranickém systému.

Otázka, co ještě je a co už není štěpení, provází koncept už od samého počátku. Již poměrně krátce po uveřejnění klíčového Rokkanova a Lipsetova díla začali další autoři (Taylor a Rae 1970; později Mair 1997; Tóka 1998) upozorňovat, že pojem

\footnotetext{
${ }^{4}$ Pokud jde o vymezení termínu cleavages a jeho český překlad, obšírné vysvětlení nabídl ve svém článku z roku 2007 Hloušek, který zdůrazňoval významový rozdíl v pojmech štěpení a konfliktní linie:

„[K]onfliktní linie“ [např́klad Fiala, Strmiska 1998] (...) nejlépe postihuje dynamiku soupeření, konflikt mezi jednotlivými politickými stranami a zároveň také obraz společnosti určitého státu, která je z různých důvodů politicky či kulturně rozdělena, a toto rozdělení se odráží v existenci různých soupeřících politických stran. Pojem ,„štěpeni“" reflektuje pouze segmentaci společnosti, zatímco reprezentaci cleavages politickými stranami ponechává stranou“ (Hloušek 2007: 362).
}

Nyní předkládaný text používá výrazů štěpení a konfliktní linie synonymně. 
je definován velmi vágně, což vede $\mathrm{k}$ jeho zaměňování s jakýmkoliv konfliktem nebo rozporem (Bartolini a Mair 1990: 213). Právě př́spěvek posledně jmenovaných, kteři štěpení přisoudili tři základní aspekty (tj. empirický, normativní a organizačnî), si po dlouhou dobu udržel prominentní postavení a jejich definici přijalo velké množství dalších autorů. S postupujícím časem a společenskými změnami se ale vztah $\mathrm{k}$ definici měnil. Nedochází ani tak k jejímu zpochybnění, jako spíše ke konstatování, že její použití v kontextu vzrůstající sociální mobility by koncept štěpení v podstatě pohřbilo, nebot' v současném světě je podle Kriesiho (2010: 673) obtížné najít takovou míru uzavřenosti, kterou předpokládali Bartolini a Mair.

Na jinou sociální realitu tedy reagoval K. Deegan-Krause (2006) inovovaným pojetím významu štěpení. Upozorňuje, že v určitých př́padech v určitém časovém období bylo možné nalézt prrípady, které naplňovaly všechny tři aspekty podle Bartoliniho a Maira, ovšem analýza dalších př́padů, kde jeden z aspektů chyběl, ztroskotala na absenci pojmu, který by toto „částečné“ štěpení uspokojivě popsal. Nabízí proto poměrně sofistikovanou definici, která kombinuje tři základní elementy - postoje, instituce a strukturu. Pro prípad, že konflikt se odehrává pouze na jedné úrovni, použivá výraz difference, pokud jde o dvě úrovně, jedná se o divide. Full cleavage pak odpovídá výše zmíněné „klasické“ definici, nebot' se jedná o kombinaci na úrovni struktury, postojů i institucionálního vyjádření (DeeganKrause 2006: 539-540). Takto pojatá definice navíc umožňuje obsáhnout rostoucí význam konfliktů okolo určitých témat.

S vlastním pojetím přichází i Z. Enyedy, který přiznává, že definice Bartoliniho a Maira je v současné době obtížně aplikovatelná a dodává, že štěpení je „,vzorcem politické soutěže zakotveným v kognitivní, emotivní nebo sociální struktuře občanů, v protikladu k soutěži, kterou určují každodenní problémy, hodnocení výkonu vlády či konkrétní osobnosti“ (Enyedi 2005: 698). Předkládaný text, podobně jako většina autorů v poslední době (např́klad Bartolini, Mair, Bornschier, Deegan-Krause nebo Kriesi), prosazuje kompromisní řešení nacházející se mezi užším a širším pojetím štěpení, přičemž užší je s přihlédnutím k cílům článku jako svébytná možnost předem vyloučeno. Na rozdíl od širokého pojetí, které podle Hlouška (2007: 366) rezignuje na organizační aspekt a prvek konfliktu, se ale text takto výrazné redukci snaží vyhnout.

V současné debatě o štěpení obecně lze vysledovat určité trendy a směry. Pokud jde o makroúroveň, oproti původnímu pojetí se téměř vytratila hypotéza o zamrznutí západoevropských stranických systémů. Platnost teze byla zpochybněna již v průběhu 70. a 80. let (viz Dalton, Flanagan a Beck 1984; Lane a Ersson 1997), přesto jde o jednu z klíčových myšlenek výzkumu stranických systémů, a proto na ni aspoň krátce odkazuje i množství současných autorů (např́lklad Bornschier 2009; Kriesi 2010; Bértoa 2012 a Tóka a Gosselin 2010).

Dochází i k teritoriálnímu posunu, kdy se ho popředí zájmu badatelů dostávají i oblasti mimo západní Evropu. Nejprve se jednalo hlavně o demokratizací 
procházející jihoamerické a středo- a východoevropské státy, v současné době pak dochází k aplikaci štěpení na politické systémy všech kontinentů (Bornschier 2009). Ve vztahu $\mathrm{k}$ materiální vs. postmateriální dimenzi je vhodné zmínit výzkum A. Morena (1999), který ovšem došel k závěru, že v př́padě Jižní Ameriky jsou specifika jednotlivých států ještě výraznější než v západní Evropě a obecně mají větší význam konfliktní linie spojené třídní príslušností.

Poměrně výrazným trendem je i posun směrem k mikroúrovni a individuálním charakteristikám, které ovlivňují spojení s politickou stranou (či jiným institucionálním vyjádřením). Tímto směrem se ubírá výzkum např́ílad $M$. Doležala (2010, 2012), R. Stubagera (2009), W. Van der Bruga (2010), A. Henjak (2010) nebo O. Knutsena (2010). Zároveň se v posledních letech dostává znovu do popření směr snažící se lépe postihnout roli aktérů (např́klad Hosli a Arnold 2010; Bornschier 2009, 2012). Přestože určité výzkumy proběhly i dříve (viz Zuckerman 1975; Przeworski a Sprague 1986; Mair 1997), nebyly propojené natolik, aby se dalo mluvit o směru či trendu.

Patrně nejzajímavější posun přineslo doplnění původních čtyř konfliktních linií o další dimenze. Kromě zkoumané postmateriální-materiální jde např́klad o dimenzi autoritarismus-libertariánství, dále štěpení definované postojem k evropské integraci a globalizaci (některými autory označované jako integrationdemarcation; Hutter 2014) a podobně. Mezi autory těchto inovací patři mj. R. Inglehart (1971, 1977, 1990), Dalton et. al. (1984), A. Lijphart (1981, 1990), H. Kitschelt (1995), G. Sartori (2005), Kriesi et. al. (2006, 2008, 2010), R. Stubager (2009), H.-P. Kriesi (2010) nebo S. Bornschier (2010). Tým okolo Kriesiho mluví ještě o štěpení mezi tzv. vítězi a poraženými globalizace, které ale dle jejich zjišsění nevytváří novou dimenzi, nýbrž je inkorporováno do stávající socioekonomické a kulturní dimenze (Kriesi et. al. 2005).

\section{b. Od štěpení k postmateriálnímu štěpení}

Současnou debatu okolo postmaterálního štěpení lze shrnout do několika nejpodstatnějších trendů - zaprvé jde o zkoumání toho, jak k formování těchto postojů dochází, jakým způsobem je lze měřit a jaké proměnné je ovlivňují; zadruhé o zkoumání samotných politických dopadů; a konečně za třetí o sledování postmateriálních hodnot $\mathrm{v}$ jednotlivých zemích $\mathrm{v}$ kombinaci $\mathrm{s}$ další proměnnou, či ve srovnání různých časových období.

Přestože při rozboru možností aplikace postmateriálního štěpení na substátní úrovně politických systémů je primární otázka projevů štěpení, lze ho jen těžko oddělit od analýzy postmateriálních hodnot jako takových, a to tím spíše, že na způsob měření postmateriálních hodnot je zaměřena poměrně velká část současné literatury.

Otázka, jak vůbec postmateriální hodnoty definovat a měřit, provází koncept postmateriálního štěpení od okamžiku, kdy Inglehart (1971, 1979) přišel se svojí 
tezí tiché revoluce. Podle Ingleharta budou občané vyspělých industrializovaných zemí narození po druhé světové válce pravděpodobněji dávat přednost postmateriálním hodnotám, upřednostňovat svobodu projevu a požadovat větší vliv na politické rozhodování. Materialisté budou naopak upřednostňovat ekonomická a bezpečnostní témata.

Přestože na významné roli hodnot $\mathrm{v}$ politickém rozhodování se shodne množství autorů, Inglehartova teze spojující postmaterialismus s generacemi prožívající formativní věk v období poválečného blahobytu a rozvoje je i častým terčem kritiky. Patrně nejznámější byla v této oblasti tzv. „debata InglehartFlanagan“, v níž druhý jmenovaný zastával pozici, že Inglehartem naměřené hodnoty odpovídají liberálním, respektive konzervativním postojům a nejedná se tedy o nové štěpení (Flanagan 1979, 2003). Spory ohledně Inglehartových tezí byly ovšem mnohem rozsáhlejší: Jeden z Inglehartových spolupracovníků P. Abramson věnoval následným debatám př́spěvek na konferenci Global Cultural Changes Conferences $\mathrm{v}$ německém Lüneburgu a ve své analýze došel k celkovému počtu 48 prríspěvků publikovaných $\mathrm{v}$ anglickém a francouzském jazyce mezi roky 1971 a 2007 (Abramson 2011).

Mezi další současné autory, kteří se dlouhodobě věnují otázce postmateriálního štěpení, avšak vůči Inglehartovým nástrojům jsou spíše skeptičtí, patří B. Trantern a M. Western (2003). Ti odmítají Inglehartem prosazovaný lineární vztah věku a hodnot, což dokládají výzkumem vztahu mezi věkem a postmateriálními hodnotami v Austrálii, kde tento vztah vyšel i při použití Inglehartova indexu poměrně slabý. Při formování postmateriálních hodnot zdůrazňují důležitost podoby stranického systému. Existuje-li $\mathrm{v}$ politickém systému více stran, je pravděpodobné, že mezi nimi budou zastoupení i Zelení nebo jiné strany vycházející z tzv. nových sociálních hnutí, díky nimž se tato témata intenzivněji objevují ve veřejném prostoru, což následně vede ke zvýšení hladiny postmateriálních hodnot ve společnosti (tamtéž: 251).

Pohled na formování hodnotové orientace nabídl i G. Marks (1997), podle nějž hraje roli množství různých procesů (socializace $\mathrm{v}$ rodině, pocit bezpečí v rodině i ve společnosti ve formativním období, vzdělání a obecně aktuální vlivy), z nichž nelze žádný vyloučit jako méně podstatný. Přestože pozdějši zkušenosti (naprŕíklad dosažené vzdělání nebo posun do jiné sociální třídy) se taktéž podílejí na formování hodnotových postojů, obecně má primární vliv socializace v rodině a pocit bezpečí (fyzického i ekonomického) na prahu dospělosti. Dle Markse již tedy pro vysvětlení nestačí Inglehartova původní teorie související s poválečným blahobytem.

Další dimenzi do již naznačeného vztahu mezi postmateriálními hodnotami a politickou participací vnášejí M. Sotirovic a J. McLeod (2001), kteří do analýzy zahrnují i téma médií a způsobu zpracování mediálního obsahu. Dle jejich výzkumu postmateriální postoje se pozitivně projevují na sledování aktuálních záležitostí v médiích a zároveň jejich kritickém hodnocení, což participaci podporuje, zatímco 
materiální postoje tendují spíše k preferování zábavného mediálního obsahu a pasivnějš́ího prístupu.

Přestože mezi postmateriální hodnoty byly tradičně řazeny otázky kvality života, politické participace, lidských práv či práv menšin, v oblasti politických projevů je dominantní především otázka životního prostředí, a to již s ohledem na fakt, že z mnoha politických a občanských hnutí se do podoby funkčních politických stran etablovala právě ta ekologická. Že se v současné době dimenze materiální-postmateriální hodnoty týká v první řadě otázek životního prostředí naznačuje i práce Knutsena (2010), který při zkoumání hodnotových postojů explicitně využívá dichotomii environmentální hodnoty versus ekonomický růst, nebo Seippela (1999). Spojení postmateriálních hodnot a podpory environmentálních hnutí zkoumá na případu Austrálie B. Tranter (2011). Přestože postmateriální hodnoty jsou jedním z prediktorů zájmu o environmentální otázky, důležitou roli hraje hlavně vysokoškolské vzdělání, v čemž se autor shoduje s Inglehartem (1997). Zmiňuje i roli stranických lídrů v utváření postojů k environmentálním otázkám, nebot' jsou to podle Trantera právě nejvyšší představitelé stran, kdo zjednodušují politický proces pro př́znivce stran, kteř́i jinak téma př́liš nesledují (Tranter 2011: 92) Australský př́pad zvolil i S. Blount (1998), který znovu analyzoval debatu o roli postmateriálních hodnot a následné volbě minoritních stran v senátních volbách 1990 a došel k potvrzení tohoto vztahu. Inglehart a Welzel (2005: 84-85) se pak domnívají, že postmateriální hodnoty lze vnímat jako indikátor odkazující $\mathrm{k}$ posílení důrazu na sebevyjádření a lidský vývoj ve společnostech, kde dochází v souvislosti s ekonomickým rozvojem k demokratizaci. Masový rozvoj postmateriálních hodnot má dle jejich výzkumu silný kauzální dopad na demokratizaci a míru svobody, což dle jejich slov dosavadní literatura opomíjela (tamtéž:: 100). Naopak pokles významu postmateriálních hodnot v souvislosti se změnou režimu naznačuje starší práce D. Fuchse a R. Rohrschneidera (1998), kteři zkoumali projevy postmateriálního štěpení ve volebních výsledcích po sjednocení Východního a Západního Německa. Zvýšená důležitost témat jako ekonomické zajištění a bezpečnost vedla $\mathrm{k}$ výraznému nárůstu materialistických postojů ve společnosti a nutnosti stran na tyto posuny adekvátně reagovat. Dle P. Warwicka je postmateriální dimenze dokonce jednou ze tř́ klíčových dimenzí, které charakterizují západoevropský politický prostor, a to vedle klasické dichotomie levice-pravice a dimenze sociální kontroly (Warwick 2002: 116).

\section{c. Aplikace na substátní úrovně - napůl cesty?}

Přestože od vydání zásadního Rokkanova a Lipsetova textu uplynulo pưlstoletí, pokusů o jeho přenesení na nižší úrovně existuje poměrně málo. Ještě méně často se potom jedná o postmateriální dimenzi. Z tohoto důvodu jsou v této části analyzovány texty, které se týkají substátní aplikace štěpení obecně či jiné než 
postmateriální dimenze, ${ }^{5}$ a to s cílem postihnout co nejvíce možných př́stupů, jak $\mathrm{k}$ aplikaci na nižší úrovně postupovat.

Přenést koncept štěpení na lokální úroveň se pokusili např́iklad M. Kubálek a V. Bubeníček (2010). Štěpení v tomto př́padě sloužilo spíše jako analytický nástroj při zkoumání konkrétního politického prostoru. Sami autoři uvádějí, že cílem textu bylo mj. prostřednictvím zvolené prrípadové studie „prozkoumat a interpretovat lokální konfliktní linii a její souvislosti“, identifikovat „hlavní konfliktní linie“ ve zkoumaných obcích a „ukázat, jak jednotlivé teoretické a metodické prŕstupy používané ve studiích komunálního politického procesu mohou př́spět k eventuálnímu zpřesňování závěrů." (Bubeníček a Kubálek 2010: 31-32). Přestože text pracuje často s pojmem konfliktní linie, nedozvíme se, jaké pojetí konfliktních linií autoři zvolili, což lze ale připsat teoretickému ukotvení článku, které se ubírá spíše směrem k politickému procesu a možnostem interpretace volebních výsledků a participace $\mathrm{v}$ malých obcích. Z deklarace, že „[p]odstata konfliktu má nicméně trvalejší charakter a lze ho tak označit za konfliktní linii, respektive rozpor definovaný odlišnými vizemi budoucího rozvoje obce, jež má své konkrétní reprezentanty - starousedlíky a Pražáky (dle vzájemného označení obou skupin), respektive „zastánce skanzenu“ a „vizionáře“ (zastánce lázeňského města)“ (tamtéž: 38) se ale lze domnívat, že pracují se spíše širším pojetím štěpení jakožto trvalejšího konfliktu. Pokud jde o uzpůsobení konceptu štěpení pro lokální úroveň, nevěnují se autoři ani tak štěpení, jako spíše vymezení prostředí malé obce jakožto specifického politického prostoru.

Propojení konceptu postmateriálního štěpení a lokální úrovně lze nalézt v nedávném textu S. Balíka (2016). Přestože závěrem jeho článku je potvrzení, že na lokální úrovni se setkáváme se zcela běžným politickým prostorem, a to i přes mnoha zastupiteli často deklarovanou apolitičnost, věnuje se štěpení poměrně obsáhle. Ve svém textu pracuje prímo s konceptem lokálních štěpení, která mohou být pozorována $\mathrm{v}$ českém prostředí. Některá z nich jsou založena na specifikách lokálních jednotek, jiná jsou odvozená od národní úrovně. Postmateriální štěpení patř́i mezi druhé jmenované a na místní úrovni je nejčastěji demonstrováno formou environmentálních konfliktů. Autor neopomíná ale ani další prvky obsažené v postmateriální-materiální dichotomii, kterou jsou např́ílad práva menšin (což ilustruje na otázce, zda má samospráva podpořit pochod Gay Pride a podobných př́kladech; viz Balík 2016: 82-83). Dodává ale, že přes možnou existenci postmateriálního štěpení na lokální úrovni je tato dimenze jednou z těch, která se zejména v malých obcích vůbec nemusí projevit (Balík 2016: 83).

\footnotetext{
${ }^{5}$ Naopak zahrnuty nebyly texty, které sice na substátní úrovni spojují postmateriální hodnoty a vládnutí, ale nijak nepracují s pojmy štěpení, a to ani v jeho nejširší podobě. Př́kladem může být článek L. Blumeho a D. Sacka (2008) o vztahu postmateriálních hodnot a důvěry (jakožto klíčových komponent sociálního kapitálu) a způsobu vládnutí $\mathrm{v}$ západoněmeckých regionech.
} 
S př́padnou odlišností lokálního prostoru při použití konceptu původně určeného pro národní úroveň se Balík vypořádává jednak v rovině politických stran a jednak ve vztahu $\mathrm{k}$ trvalosti konfliktu. S pojmem strana/stranický zachází $\mathrm{v}$,instrumentálním slova smyslu, kdy jím popisuje současně i politická hnutí nebo místní sdružení nezávislých kandidátư“ (Balík 2016: 74). Zároveň uznává, že některá štěpení se mohou vyskytnout pouze ve formě krátkodobého konfliktu a nevyvinou se v dlouhodobou politickou otázku, což je klíčový prvek Rokkanova modelu; jejich důležitost ovšem tkví v tom, že za určitých okolností mohou mít vliv na strukturu místní politické komunity i v dlouhodobém měřítku (Balík 2016: 79). Jako určité vymezení odlišnosti štěpení na lokální úrovni lze vnímat i to, že autor používá termín contradiction a nikoliv cleavage, což by odkazovalo taktéž spiše k širšímu pojetí.

Cílené využití postmateriálního štěpení na lokální úrovni představuje text $\mathrm{K}$. Musilové zaměřený na spor okolo Národního parku Šumava, pracující s definicí podle Bartoliniho a Maira. Problematiku jejího využití diskutuje autorka důkladněji až $\mathrm{v}$ závěru, kde přiznává nutnost šiŕeji interpretovat jednotlivé znaky definice. $\mathrm{V}$ průběhu textu ale otázku, zda je při takto pojaté interpretaci vůbec vhodné volit zmíněnou definici, spíše neřeší.

Substátní úroveň a politické projevy postmateriálních hodnotových postojů explicitně spojuje článek J. Vanderleeuwa, M. Sandovici a C. Jarmona (2011), který zkoumá rozvojové priority žen-starostek v USA právě v kontextu postmateriálních hodnot. Autoři navazují na Ingleharta (1977) v tom smyslu, že v př́padě ekonomického rozvoje lze spatřovat rozpor mezi postmateriálními a tradičními hodnotami, kdy prvně jmenované reprezentují ohled na kvalitu života a ekologii, zatímco druhé ekonomickou stabilitu, dostatek pracovních míst a podobně. Docházejí $\mathrm{k}$ závěru, že v ekonomickém rozvoji na lokální úrovni se již z podstaty věci prosazují tradiční hodnoty bez ohledu na pohlaví představitelů, v prŕípadě žen ale autoři shledali větší míru ohledu na životní prostředí. Přestože článek propojuje hodnoty a jejich politické projevy, nejedná se využití konceptu štěpení.

Regionální úroveň při zkoumání štěpení zastupuje O. Knutsen (2010), který si kladl otázku, jak je možné vysvětlit odlišnou podporu politických stran v jednotlivých regionech. Hodnotová orientace byla pak vedle sociální struktury a teritoriální identity jednou ze zkoumaných proměnných. Pro analýzu vztahu mezi hodnotovou orientací a výběrem strany zvolil Knusen čtyři dimenze, a to na osách náboženská orientace - sekulární hodnoty, ekonomická levice - pravice, liberální autoritativní postoje a „zelené“ hodnoty a ekologie - orientace na ekonomický růst (Knutsen 2010: 569-570). Knutsen odkazuje na Ingleharta a postmateriální hodnoty spojuje s tzv. new politics, na kterou odkazuje posledně jmenovaná dimenze. Z autorových zjištění ale vyplynulo, že hodnotová orientace hrála v regionálním štěpení roli pouze na straně tradičních hodnot a tzv. old politics. Sama teritoriální identita se nakonec ukázala být méně důležitou než hodnotová orientace a sociální struktura (tamtéž: 578). Přestože se výzkum zabýval evropskými regiony, nebylo přizpůsobení pojmu štěpení na jinou než národní úroveň nutné, a to z toho důvodu, 
že autor pracuje s údaji o volebním chování, čili jiné projevy štěpení než prostřednictvím volby určité strany nezkoumal.

Posledním zahrnutým autorem je J. Van der Veer (1994), který naznačuje štěpení mezi metropolitními centry a bohatšími předměstími. Pojem štěpení je zde použit jako synonymum pro dlouhodobě zakořeněné sociální rozdělení mezi jednotlivými lokalitami.

Tabulka 1: dosavadní použití cleavages na substátních úrovních

\begin{tabular}{|c|c|c|c|c|c|}
\hline & Úroveň & $\begin{array}{l}\text { Vymeze- } \\
\text { ní pojmu } \\
\text { štěpení }\end{array}$ & $\begin{array}{l}\text { Uzpůsobení } \\
\text { substátní } \\
\text { úrovni }\end{array}$ & Dimenze & $\begin{array}{l}\text { Postmat. } \\
\text { dimenze }\end{array}$ \\
\hline Balík 2016 & lokální & + & + & $\begin{array}{l}\text { Rozvoj - zachování } \\
\text { původního charakteru; } \\
\text { starousedlíci - noví } \\
\text { obyvatelé; centrum - } \\
\text { periferie; různé } \\
\text { zájmové organizace; } \\
\text { jednotlivec - } \\
\text { komunita; rozsah } \\
\text { funkcí obce; } \\
\text { náboženské rozdělení; } \\
\text { pracovní síla - kapitál; } \\
\text { postmateriální- } \\
\text { materiální postoje; } \\
\text { vztah k původnímu } \\
\text { režimu; genderové } \\
\text { rozdělení }\end{array}$ & + \\
\hline Musilová 2016 & $\begin{array}{c}\text { Lokální } \\
\text { a regionální }\end{array}$ & + & + & $\begin{array}{l}\text { Postmateriální - } \\
\text { materiální }\end{array}$ & + \\
\hline $\begin{array}{l}\text { Vanderleeuw, } \\
\text { Sandovici a } \\
\text { Jarmon } 2011\end{array}$ & Lokální & - & - & $\begin{array}{l}\text { Materiální - } \\
\text { postmateriální }\end{array}$ & + \\
\hline $\begin{array}{l}\text { Bubeníčk a } \\
\text { Kubálek } 2010\end{array}$ & Lokální & $(+)$ & $(+)$ & $\begin{array}{c}\text { Starousedlíci - noví } \\
\text { obyvatelé }\end{array}$ & - \\
\hline Knutsen 2010 & Regionální & + & + & $\begin{array}{c}\text { Centrum - } \\
\text { periferie/ regionální } \\
\text { šěpení; „old - new } \\
\text { politics" }\end{array}$ & + \\
\hline
\end{tabular}

Zdroj: autorka

Vysvětlivky: + znamená definici či explicitní vymezení, (+) částečné nebo implicitní vymezení, - absenci vymezení. 


\section{Víceúrovňové vládnutí jako nástroj zpětného ověření?}

Víceúrovňové vládnutí bylo zvoleno jako analytický nástroj pro zachycení specifičnosti zkoumaných substátních úrovní a zároveň jako instrument umožňující zpětnou verifikaci dosavadních zjištění. Nejde o jediný směr, který zkoumá postupný př́sun moci od centra na jiné úrovně, jeho význam v kontextu tohoto článku ale spočívá jednak v tom, že neopomíjí lokální úroveň, jednak v zachycení dynamiky těchto procesů.

Pokud jde o roli lokální úrovně, je zásadní přidanou hodnotou konceptu to, že „nabízí nový pohled na roli lokální politiky tím, že explicitně zmiňuje její podíl na evropském vládnutí“ (Havlík 2013: 43). Lokální úroveň kromě samotných autorů pojmu víceúrovňového vládnutí Liesbet Hooghe a Garyho Markse uvádějí explicitně i T. Cottier a M. Hertig. Ti mluví až o 5 úrovních - lokální, státní ve federálních systémech, federální úrovni, úrovni regionální integrace a globální úrovni (Cottier a Hertig 2003, cit. dle Zürn, Wälti a Enderlein 2011: 8). Za užitečný nástroj bádání považují tento koncept i D. Birrell a C. Gormley-Heenan (2015: 7).

Právě na lokální úrovni bylo možné sledovat potenciální kontradikce, které se později staly jádrem konceptu dvou typů víceúrovňového vládnutí. Jak na př́kladu místních komunit v USA v 70. letech uvádějí Hooghe a Marks (2002), existuje poměrně široká shoda na tom, že určitý typ služeb je nejvhodnější soustředit prímo na místní úrovni. Naskýtá se ovšem otázka, jak se vypořádat s rozdělením pravomocí nad těmito službami a související odpovědností. Jeden z pohledů navrhuje soustředit pravomoci $\mathrm{v}$ poskytování služeb $\mathrm{v}$ určité oblasti (ve smyslu místní komunity) do jediné jednotky s cílem jednak úspor z rozsahu a jednak lépe stanovitelné politické odpovědnosti (Hooghe a Marks 2002: 233). Druhý pohled naopak doporučuje existenci několika vzájemně se překrývajících účelově zaměřených jurisdikcí, které umožňují občanům volbu mezi několika možnostmi. (tamtéž: 233) Podobný rozpor potom Hooghe a Marks identifikují i na př́padu evropské integrace, kde taktéž existují vzájemně si odporující př́ístupy, z nichž jeden počítá s koherentním systémem národních vlád podléhajících $\mathrm{v}$ určitých oblastech společné jurisdikci, druhý naopak s navzájem se překrývající působností různých režimů, kde by si příslušnost volily samotné státy (tamtéž: 234).

Původní koncept víceúrovňového vládnutí byl podle některých autorů vytvořen s cílem zachytit specifické vztahy aktérů v oblasti regionální a strukturální politiky (Knodt a Hüttmann 2006: 226, cit. dle Havlík 2013: 41). Marks píše o multi-level governance jako o „systému neustálého vyjednávání mezi ,nested governments' na několika teritoriálních úrovních - supranacionální, národní, regionální a lokální, jako výsledku širokého procesu institucionální tvorby a relokace rozhodování, která přenesla původně centralizované funkce státu na supranacionální úroveň a některé dolů na lokální/regionální úroveň “ (Marks 1993: 392, cit. dle Havlík 2013: 42). 
Postupem doby došlo $\mathrm{k}$ určitému přepracování konceptu víceúrovňového vládnutí, který byl na základě výše zmíněné dichotomie mezi soustředěním pravomocí a překrývajícími se kompetencemi doplněn o dva ideální modely, tzv. Typ I a Typ II. Typ I ideově vychází z federalismu a charakterizuje omezený počet úrovní, jejichž hranice i pravomoci jsou jasně stanovené. Struktura a instituce každé z úrovní se navzájem podobají. Obecně se jedná o úrovně lokální, regionální (prípadně úroveň vzniklou procesem devoluce), národní, úroveň EU a supranacionální/globální (Birrell a Gormley-Heenan 2013: 9). Typ pak II odpovídá situaci, kdy existuje větší množství jednotlivých jurisdikcí, které nejsou spojeny s konkrétními úrovněmi, naopak jsou poměrně flexibilní a může docházet k jejich překrývání, nebot' jejich činnost není vázána na teritorium, ale na specifický úkol (Hooghe a Marks 2002: 236).

\section{a. Specifika substátních úrovní z pohledu víceúrovňového vládnutí}

$\mathrm{Na}$ substátní úrovně lze v rámci víceúrovňového vládnutí nahlížet dvěma způsoby. Pokud jde o institucionální nastavení a vztah s centrální úrovní, je vhodné nahlížet na ně optikou Typu I. Lokální úroveň ve většině zemí znamená zároveň úroveň nejnižší, v př́padě Skotska a Walesu jde dokonce o úrovně dvě (Birrell a GormleyHeenan 2015: 10). Místní orgány jsou volené, z čehož plyne, že lokální vláda si může nárokovat demokratický mandát podobně jako ta na národní úrovni (tamtéž: 10) To samé platí pro úroveň regionální. Přestože $\mathrm{v}$ jednotlivých státech se funkce svěrené nižším úrovním mohou odlišovat, některé charakteristiky po funkční stránce jednotlivé systémy sdílejí: Jedná se např́íklad o poskytování služeb v sociální oblasti a základního školství, plánování, kulturní či sportovní život komunity a technické záležitosti na úrovni lokální, a dále oblasti zdravotnictví, školství, sociálního zabezpečení, dopravy a životního prostředí na úrovni regionální (tamtéž: 10-12). Míra finanční autonomie je $\mathrm{v}$ jednotlivých systémech odlišná a podobně jako míra decentralizace je odvozena od centrální vlády. Z toho vyplývá určitá podřízenost lokální a regionální úrovně projevující se používáním množstvím kontrolních mechanismů ze strany centra (tamtéž: 11).

Typ II potom odpovídá situaci, kdy jsou služby poskytovány množstvím specifických asociací, které se mohou překrývat či dokonce navzájem vytvářet konkurenci. Tento model se vyskytuje např́klad ve Švýcarsku, funkčně se tomuto nastavení blíźí i systém v USA (Hooghe a Marks 2002: 236). Př́kladem jednotek, které operují v rámci takového uspořádání, jsou např́klad britské QUANGOS, kvazi-autonomní nevládní organizace poskytující služby. $\mathrm{Na}$ rozdíl od výše zmíněného typu jsou představitelé těchto jednotek jmenováni, což vede k časté kritice a pochybnostem o jejich odpovědnosti. 


\section{Syntéza}

Koncept štěpení sice plně nedostačuje k vysvětlení změn v současných stranických systémech na celostátní úrovni, je ale stále schopen zachytit nové dimenze konfliktů, které strany musejí aspoň do určité míry adoptovat, mají-li být schopny uspět ve volební soutěži. Hlubší zamyšlení nad možností aplikace postmateriálního štěpení nabízí rozbor odpovědí na položené výzkumné otázky:

\section{Je koncept postmateriálního štépeni spojen výlučnè s národni úrovni?}

Jak podotýkají někteří autoři (Deegan-Krause 2006; Enyedy 2005; Kriesi 2010 či Bornschier 2012), koncept postmateriálního štěpení byl, podobně jako původní Rokkanův a Lipsetův koncept, určen primárně pro vysvětlení změny stranického systému na celostátní úrovni a v současné realitě by již nedostačoval. Namísto zavrhnutí je ale možné jej využít pro zkoumání jiných úrovní tak, jak to dělá např́klad Balík (2016). Ten sice prriznává, že tento typ štěpení nelze automaticky identifikovat ve všech obcích, jinak je ale jeho přenesení na lokální úroveň možné. Jako prŕklad prostoru, kde se bude postmateriální štěpení hledat hưře, uvádí malé obce. S ohledem na dominanci problematiky životního prostředí $\mathrm{v}$ oblasti postmateriálního štěpení je ale možné hledat ho i v menších jednotkách, a to právě v souvislosti s environmentální problematikou (viz Musilová 2016). S posilováním rolí měst či regionů v environmentálních otázkách (Homsy a Warner 2015; Lee a Koski 2015) se rozšíŕení postmateriálního štěpení na substátní úrovně naopak př́mo nabízí.

\section{Jaké jsou predpoklady aplikace na substátni úrovné?}

Aplikace na substátní úrovně vyžaduje v první řadě odklon od užšího pojetí a určité změny v použité definici, at' již je zvolena jakkoliv. Definice podle Bartoliniho a Maira není vyloučená, ale použití zejména na lokální úrovni by velmi pravděpodobně vedlo $\mathrm{k}$ nutnosti šířeji interpretovat význam empirického, normativního a především organizačního aspektu, a to s ohledem na specifickou podobu municipálních politických systémů. Je totiž nutné ve zkoumání zohlednit rozdílnou strukturu aktérů. V některých zemích je vedle tradičních politických stran běžný výskyt nezávislých sdružení (viz Balík 2016), př́ípadně úplná absence stran. Za organizační vyjádření konfliktu lze pak považovat např́klad zájmová sdružení, která často zastávají roli, kterou by na národní úrovni hrály politické strany. V tomto ohledu je vhodné vztáhnout se $\mathrm{k}$ dříve rozebíranému konceptu víceúrovňového vládnutí, díky kterému lze identifikovat klíčové prvky, které spojují lokální úroveň i navzdory často odlišnému fungování $\mathrm{v}$ jednotlivých zemích. Zcela zásadní je v této perspektivě moment volby jednotlivých zástupců lokální či regionální úrovně, který umožňuje považovat i tuto úroveň za určitý odraz politického uspořádání dané lokality a tím pádem podporuje myšlenku aplikovat i zde koncept štěpení. 


\section{Jaké jsou odlišné projevy na rĩzných úrovnich?}

Při pohledu na klasické texty o štěpení i na nejnovější literaturu lze konstatovat, že při zkoumání odlišných projevů štěpení hraje kromě samotné úrovně roli i velikost zkoumané jednotky. Př́kladem může být výše zmíněný Knutsenův (2010) článek, jehož výzkumný design by mohl odpovídat i celostátní úrovni, a to díky zahrnutí množství dostupných dat a způsobu analýzy.

Jedná-li se naopak o lokální úroveň ve smyslu jednotlivých obcí či měst, jsou projevy odlišné, nebot' organizační vyjádření štěpení nabývá zcela jiných forem než na úrovni celonárodní. Roli politických stran zde mohou zastávat i nezávislá sdružení či spolky vázané pouze na konkrétní samosprávu; u místních sdružení politických stran potom nelze spoléhat na to, že budou reprezentovat stejnou politiku jako jejich ústředí. S velikostí jednotek souvisí i dostupnost dat. V př́padě postmateriálního štěpení se výzkumy na celostátní úrovni neobejdou bez sociologických šetření zaměřených na hodnotovou orientaci, která ovšem mohou být značnou komplikací na úrovni jednotlivých obcí či měst (nejde-li prŕmo o metropole či jednotky o velikosti stovek tisíc obyvatel). Postmateriální štěpení na úrovni obcí lze tedy při nedostupnosti hodnotových průzkumů demonstrovat např́klad na volebních ziscích jednotlivých kandidujících uskupení a způsobu, kterým tato uskupení či hnutí přistupují k určitým tématům.

$Z$ konfrontace $s$ víceúrovňovým vládnutím vystupuje i důležitost institucionálního nastavení vztahů jednotlivých úrovní a míra svěrených pravomocí i kontroly. Ve vztahu k postmateriálnímu štěpení již byla diskutována role měst či regionů $\mathrm{v}$ environmentálních otázkách, významný potenciál má ale i problematika územního rozvoje a plánování, která je velmi často delegována na nižší úrovně a často se v ní střetávají vize o hospodářském rozvoji jednotek se snahou o ochranu životního prostředí či jen zachování podoby krajiny nebo zástavby.

\section{Závěr}

Diskuze nad výzkumnými otázkami ukazuje, že aplikace postmateriálního štěpení mimo národní úroveň možná je. Vyžaduje ovšem určité změny a nelze tedy uvažovat nad pouhým mechanickým přesunutím. Problematické může být především organizační či institucionální vyjádření konfliktu, nebot' přilišné rozvolnění v tomto aspektu mưže vést $\mathrm{k}$ natolik širokému pojetí, že už nelze mluvit o štépení. Zejména stranické systémy, s jejichž formováním je štěpení spjato, nabývají na lokální úrovni různé podoby, a to především $\mathrm{v}$ důsledku př́tomnosti specifických politických aktérů.

Př́klady dosavadní aplikace konceptu štěpení na substátní úrovně ukazují i určité rozdíly mezi jednotlivými zeměmi. Municipální struktura České republiky je svou rozdrobeností a vysokým počtem malých obcí evropském kontextu unikátem, což vede i k tomu, že v současné české debatě lze nalézt prríspěvky zkoumající 
štěpení na takto malých jednotkách. Z logiky věci se jí naopak vyhýbají výzkumy řešící tuto problematiku v kontextu metropolí či velkých měst a jejich předměstí.

Pro budoucí výzkum je pak vhodné položit si otázku, jak lépe uchopit postmateriální štěpení na nižších úrovních ve smyslu důkladnějšího provázání hodnotové orientace a politického vyjádření, což současný text v tuto chvíli plně zodpovědět nedokáže.

\section{Literatura a prameny}

Abramson, Paul. R (2011): „Critiques and Counter-Critiques of the Postmaterialism Thesis: Thirty-four Years of Debate.“ CSD Working Papers, online (http://escholarship.org/ uc/item/3f72v9q4), [ověřeno k 27. 1. 2017].

Balík, Stanislav (2008). Ceská komunální politika v obcich s rozsirirenou puisobností. Koalice, voličské vzorce a politické strany na mistni úrovni v letech 1994-2006. Brno: CDK.

Balík, Stanislav (2016): „Local Cleavages, Politics and Policy at the Local Level - Is the Depolitization Real?" Sociálni studia / Social Studies 13(1): 73-85.

Bartolini, Stefano a Peter Mair (1990): Identity, competition, and electoral availability: the stabilisation of European electorates 1885-1985. Cambridge: Cambridge University Press.

Bertoa, Fernando Casal (2014): „Party systems and cleavage structures revisited: A sociological explanation of party system institutionalization in East Central Europe." Party Politics, (2)1: 16-36. DOI: 10.1177/1354068811436042

Birrell, Derek a Cathy Gormley-Heenan. (2015): Multi-Level Governance and Northern Ireland. Basingstoke: Palgrave Macmillan.

Blais, André, Donald E. Blake a Stéphane Dion (1990): „The Public/Private Sector Cleavage in North America: The Political Behavior and Attitudes of Public Sector Employees.“ Comparative Political Studies 23(3): 381-403. DOI: 10.1177/0010414090023003005

Blount, Simon (1998): „Postmaterialism and the Vote for the Senate in Australia.“ Australian Journal of Political Science 33(3): 441-449. DOI: 10.1080/10361149850561

Blume, Lorenz a Detlef Sack (2008): „Patterns of Social Capital in West German Regions.“ European Urban and Regional Studies 15(3): 229-248. DOI: 10.1177/0969776408090416

Bornschier, Simon (2009): „Cleavage Politics in Old and New Democracies.“ Living Reviews in Democracy 1(1): 1-13.

Bornschier, Simon (2010): „The New Cultural Divide and the Two-Dimensional Political Space in Western Europe." West European Politics 33(3): 419-444. DOI: 10.1080/01402381003654387

Bornschier, Simon (2012): „Cleavages and actors in the formation of a new cultural divide: Why a right-wing populist party emerged in France and not in Germany." European Political Science Review 4(1): 121-145. DOI: 10.1017/S1755773911000117

Brooks, Clem, Paul Nieuwbeert a Jeff Manza (2006): „Cleavage-based voting behavior in cross-national perspective: Evidence from six postwar democracies.“ Social Science Research 35 (1): 88-128.

Bubeníček, Václav a Michal Kubálek (2010): „Konfliktní linie v malých obcích.“ Acta Politologica 2(3): 30-45. 
Cantijoch, Marta a Josep San Martin (2009): „Postmaterialism and Political Participation in Spain." South European Society and Politics 14(2): 167-190. DOI: 10.1080/13608740903037901.

Cordier, Thomas (1996): „Cleavages in green parties: The gases of the Dutch, French and German Greens." Innovation: The European Journal of Social Science Research 9(4): 491-507. DOI: $10.1080 / 13511610.1996 .9968505$

Cottier, Thomas a Maya Hertig (2003): „The prospects of 21st century constitutionalism." In: von Bogdandy, Armin a Rüdiger Wolfrum (eds.), Max Planck Yearbook of United Nations Law. Leiden: Koninklijke Brill N.V., 261-328

Dalton, Russell J., Scott Flanagan a Paul Beck (eds) (1984): Electoral Change in Advanced Industrial Democracies. Realignment or Dealignment? Princeton: Princeton University Press.

Deegan-Krause, Kevin (2006): New Dimensions of Political Cleavage. In: Russel, Dalton a Hans Klingemann, Oxford Handbook of Political Science. Oxford: Oxford University Press.

Doležal, Martin (2010): „Exploring the Stabilization of a Political Force: The Social and Attitudinal Basis of Green Parties in the Age of Globalization." West European Politics 33(3): 534-552. DOI: 10.1080/01402381003654569

Doležal, Martin a Hutter, Swen (2012): „Participation and party choice: comparing the demand side of the new cleavage across arenas." In: Hanspeter Kriesi, Edgar Grande, Martin Dolezal, Marc Helbling, Dominic Höglinger, Swen Hutter, Bruno Wüest (eds.), Political Conflict in Western Europe. Cambridge: Cambridge University Press, 67-95.

Enyedi, Zsolt (2005): ,The role of agency in cleavage formation. “ European Journal of Political research 44(5): 697-720. DOI: 10.1111/j.1475-6765.2005.00244.x

Flanagan, Scott a Aie-Rie Lee (2003): „The New Politics, Culture Wars, and The Authoritarian-Libertarian Value Change in Advanced Industrial Democracies.“ Comparative Political Studies 36(3): 235-270. DOI: 10.1177/0010414002250664

Fuchs, Dieter a Robert Rohrschneider (1998): „Postmaterialism and electoral choice before and after German unification." West European Politics 21(2): 95-116. DOI: $10.1080 / 01402389808425246$

Gábor, Tóka a Tanie Gosselin (2010): „Persistent Political Divides, Electoral Volatility and Citizen Involvement: The Freezing Hypothesis in the 2004 European Election." West European Politics (33)3: 608-633. DOI: 10.1080/01402381003654619

Henjak, Andrija (2010): „Political Cleavages and Soci-economic Context: How Welfare Regimes and Historical Divisions Shape Political Cleavages." West European Politics, 33(3):474-504. DOI: 10.1080/01402381003654528

Havlík, Vratislav (2013): Města jako partner procesu vládnutí: Případ českých a německých měst. Brno: Masarykova Univerzita.

Hloušek, Vít (2002): „Koncept konfliktních linií v západní politické vědě a jeho proměny.“ Politologický ćasopis, 9(4): 398-414.

Hloušek, Vít (2007): „Koncept konfliktních linií a problematika evropské integrace.“ Sociologický časopis / Caech Sociological Review 43 (2): 361-378.

Holman, Nancy a Andy Thornley (2015): „Backlash in the London suburbs: the localstrategic tension in multilevel governance." Environment \& Planning C: Politics and Space, 33(3): 496-511. DOI: 10.1068/c13135

Homsy, George C a Mildred E. Warner (2015): „Cities and Sustainability: Polycentric Action and Multilevel Governance." Urban Affairs Review 51(1): 46-73. DOI: $10.1177 / 1078087414530545$ 
Hooghe, Liesbet a Gary Marks (2003): „Unraveling the Central State, but How? Types of Multi-Level Governance." The American Political Science Review 97(2): 233-243. DOI: 10.1017/S0003055403000649

Hosli, Madeleine O. a Arnold, Christine (2010): „,The Importance of Actor Cleavages in Negotiating the European Constitution." International Studies Quarterly 54(3): 615-632. DOI: $10.1111 / j .1468-2478.2010 .00602 . x$

Hudák, Jakub, Petr Jüptner a Jiří Svoboda (Eds.) (2003). Komunálni politické systémy. Praha: Filozofická fakulta Univerzity Karlovy.

Hutter, Sven (2014): Protesting Culture and Economics in Western Europe: New Cleavages in Left and Right Politics. Minnesota: Minnesota University Press.

Inglehart, Ronald (1990): Culture Shift in Advanced Industrial Society. Princeton: Princeton University Press.

Inglehart, Ronald (1971): „The Silent Revolution in Europe: Intergenerational Change in Post-Industrial Societies. The American Political Science Review 65(4): 991-1017. DOI: $10.2307 / 1953494$

Inglehart, Ronald (1977): The Silent Revolution: Changing Values and Political Styles Among Western Publics. Princeton: Princeton University Press.

Inglehart, Ronald (1997): Modernization and Postmodernization: Cultural, Economic, and Political Change in 43 Societies. Princeton: Princeton University Press.

Inglehart, Ronald a Christian Welzel (2005): Modernization, cultural change, and democracy: the buman development sequence, Cambridge: Cambridge University Press.

Kitschelt, Herbert a Anthony J. McGann (1995): The radical right in Western Europe: a comparative analysis. Ann Arbor: University of Michigan Press.

Knodt, Michéle a Martin Grosse Hüttmann (2006): „Der Multi-Level GovernanceAnsatz." In: Bieling, Hans-Jürgen a Marika Lerch, Theorien der europänischer Integration. Wiesbaden: VS Verlag für Sozialwissenschaften, 223-247

Knutsen, Oddbjorn (2010): „The Regional Cleavage in western Europe: Can Social Composition, Value Orientation and Territorial Identities Explain the Impact of Region on Party Choice?" West European Politics (33)3: 553-585. DOI: $10.1080 / 01402381003654577$

Kriesi, Hanspeter (2010): „Restructuration of Partisan Politics and the Emergence of a New Cleavage Based on Values." West European Politics 33(3): 673-685. DOI: 10.1080/01402381003654726

Kriesi, Hanspeter (2012): Political conflict in Western Europe, Cambridge: Cambridge University Press.

Kriesi, Hanspeter, Edgar Grande, Romain Lachat, Martin Dolezal, Simon Bornschier a Timotheos Frey (2006): ,Globalization and the transformation of the national political space: Six European countries compared.“ European Journal of Political research 45(6): 921956. DOI: 10.1111/j.1475-6765.2006.00644.x

Kriesi, Hanspeter, Edgar Grande, Romain Lachat, Martin Dolezal, Simon Bornschier a Timothy Frey (2008): Western European Politics in the Age of Globalization. Cambridge: Cambridge University Press.

Lane, Jan-Erik a Svante Ersson (1997): „Parties and Voters: What Creates the Ties?“ Scandinavian Political Studies 20(2): 179-196. DOI: 10.1111/j.1467-9477.1997.tb00191.x 
Lee, Taedong a Chris Koski (2015): „Multilevel governance and urban climate change mitigation."Environment and Planning C: Government and Policy 33(6): 1501-1517. DOI: 10.1177/0263774X15614700

Lijphart, Arend (1981): „Political Parties: Ideologies and Programs. In: Butler, David, Howard Penniman a Austin Ranney(eds), Democracy at the Polls: a Comparative Study of Competitive National Elections. Washington: American Enterprise Institute for Public Policy Research, 26-51.

Lijphart, Arendt (1990): „The Political Consequences of Electoral Laws, 1945-85.“ The American Political Science Review 84(2): 481-496. DOI: 10.2307/1963530

Mair, Peter (1997): Party System Change: Approaches and Interpretations. Wotton-under-Edge: Claredon Press.

Marks, Gary (1993): „Structural Policy and Multilevel Governance in the EC.“ In: Cafruny, Alan a Glenda Rosenthal, The State of the European Community. New Yoork: Lynne Rienner, 391-410

Marks, Gary N. (1997). The Formation of Materialist and Postmaterialist Values. Social Science Research 26(1): 52-68. DOI: 10.1006/ssre.1996.0585

Moreno, Alejandro (1999): Political Cleavages. Issues, Parties, and the Consolidation of Democracy. Boulder, CO: Westview Press.

Musilová, Karolína (2016): „Národní park Šumava a obce na jeho území: Př́ípad postmateriálního štěpení?.“ Politologická revue 22(1): 41-67.

Przeworski, Adam a John Sprague (1986): Paper Stones: A History of Electoral Socialism. Chicago: University of Chicago Press.

Rae, Douglas W. a Michael Taylor (1970): The Analysis of Political Cleavages. Yale University Press.

Sartori, Giovanni (2005): Strany a stranické systémy - Schéma pro analýzu. Brno: Centrum pro studium demokracie a kultury.

Seippel, Ørnulf (1999): „Political environmentalism: Glass interests, modern values or postmodern feelings?" Innovation: The European Journal of Social Science Research (12)2: 129_ 153. DOI: $10.1080 / 13511610.1999 .9968594$

Sotirovic, Mira a Jack M. McLeod (2001): „Values, Communication Behavior, and Political Participation." Political Communication 18(3): 273-300. DOI: 10.1080/10584600152400347

Stubager, Rune (2009): „Education-based group identity and conciousness in the authoritarian-libertarian value conflict." European Journal of Political Research, 48(2): 204 233. DOI: $10.1111 /$ j.1475-6765.2008.00834.x

Tóka, Gábor (1998): „Party Appeals and Voter Loyalty in New Democracies.“ Political Studies 46(3): 589-610. DOI: 10.1111/1467-9248.00156

Tranter, Bruce (2011): „Political divisions over cliamte change and environmental issues in Australia. Environmental Politics 20 (1): 78-96. DOI: 10.1080/09644016.2011.538167

Tranter, Bruce a Mark Western (2003): „Postmaterial Values and Age: The Case of Australia." Australian Journal of Political Science 38 (2): 239-257. DOI: 10.1080/1036114032000092701

Van der Brug, Wouter (2010): „Structural and Ideological Voting in Age Cohorts.“ West European Politics 33(3): 586-607. DOI: 10.1080/01402381003654593

Vanderleeuw, James M., Maria E. Sandovici a Christopher A. Jarmon (2011): „Women City Leaders and Postmaterialist Values: Gender Differences in Economic Development 
Priorities, Journal of Women." Politics \& Policy (32)3: 211-236. DOI: 10.1080/1554477X.2011.589289

Van der Veer, Jeroen (1994): „Metropolitan Government and City-Suburban Cleavages: Differences between Old and Young Metropolitan Areas." Urban Studies 31(7): 10571079. DOI: 10.1080/00420989420080951

Warwick, Paul (2002): „Toward a Common Dimensionality in West European Policy Spaces.“ Party Politics 8 (1): 101-122. DOI: 10.1177/1354068802008001005

Welzel, Christian a Ronald Inglehart (2005): „Liberalism, Postmaterialism, and theGrowth of Freedom." International Review of Sociology, Revue Internationale de Sociologie 15(1): 81-108. DOI: $10.1080 / 03906700500038579$

Westinen, Jussi (2015): „Cleavages - Dead and Gone? An Analysis of Cleavage Structure and Party Choice in Contemporary Finland.“ Scandinavian Political Studies 38(3): 277-300. DOI: $10.1111 / 1467-9477.12046$

Zuckermann, Alan (1975): „Political Cleavage: A Conceptual and Theoretical Analysis.“ British Journal of Political Science 5(2): 231-248. DOI: 10.1017/S0007123400008140

Zürn, Michael, Sonja Wälti a Henrik Enderlein (eds) (2011): Handbook on Multi-level Governance. Cheltenham: Edward Elgar Publishing.

\section{The Possibilities and Limits of Applying the Concept of Postmaterial Cleavage on Sub-State Levels \\ SUMMARY}

The aim of this review article is to examine the conditions under which the concept of post-material cleavages can be applied at the sub-state levels of a political system. The paper asks whether the concept of post-material cleavages is linked exclusively to the national level, what are its various manifestations at given levels, and what conditions need to be fulfilled if we want the concept to be applied on a sub-state level.

The first part of the article examines the current state of research and recounts attempts at an application of the concept of a cleavage beyond the original framework. Key texts are identified which have advanced or significantly enriched the scholarly debate. This section also discusses the currently accepted definitions of a cleavage and the possibilities and limits of their use in the sub-state context. In the core part of the article, existing attempts to apply post-material cleavages outside the national level are outlined and critically evaluated.

Using the concept of multilevel governance, the second part of the paper seeks to verify the possibility of employing the post-material cleavages at sub-state levels. In the context of the wider discussion, multilevel governance is used as a tool for highlighting the specific features of lower levels of a political systems, as well as problems that may arise when applying theoretical concepts beyond the national level. This perspective was chosen because local political systems vary considerably between countries, both functionally and territorially. It was therefore necessary to focus only on general and common 
characteristics, as opposed to the specifics of the respective political systems. The final section systematises existing approaches to the use of cleavages at the local and regional level, identifies major problems with its application, and proposes ways of coping with them.

Although political scientists have been familiar with the concept of a post-material cleavage for decades, it still remains relevant for current research, as conflicts between opposing public interests about area development and environmental protection continue to be widely discussed and have a major impact on lives of those residing in the affected areas. These are, for example, situations where the environment is threatened by a potential economic use of the site, such as raw material extraction, infrastructure construction or other extensive use of land, which, on the other hand, would likely increase the number of jobs in the area or contribute to energy independence. Recent examples include the debate on the possible breach of mining limits in North Bohemia, disputes surrounding the attempt to start shale gas extraction in the US and other countries, or the difficult search for nuclear waste storage sites.

The review of existing contributions shows that the application of the post-material cleavage beyond the national level is possible; however, such a step requires certain conceptual amendments. Especially party systems, whose formation is linked to cleavages, may have a different character at the local level due to the presence of specific political actors. Sub-state level application requires primarily a shift from a narrow concept of a cleavage as well as some minor changes in its definition. The most widely used definition by Bartolini and Mair is acceptable; however, its application on the local level would probably require an interpretive broadening of the empirical, normative and, above all, organizational aspects of the concept of a cleavage, for reasons related to the specific nature of municipal political systems. The organizational/institutional expression of a conflict may be difficult to capture, because too broadening the perspective too much could leave us with such an all-encompassing concept that it would no longer make sense to speak about cleavages. For instance, the existence of interest groups can be considered an organizational expression of a cleavage, as they often play essentially the same role on sub-state levels that political parties have at the national level. 